ISSN 0258-7122

Bangladesh J. Agril. Res. 33(3) : 523-525, September 2008

\title{
Short Communication \\ EFFICACY OF THREE TRAP CROPS AGAINST WHITEFLY TO MANAGE TOMATO YELLOW LEAF CURL VIRUS
}

\author{
ABDUL MUQIT ${ }^{1}$, ABDUL MANNAN AKANDA ${ }^{2}$ \\ AND MOHAMMED ZINNATUL ALAM ${ }^{3}$
}

Production of tomato is hampered by many diseases in the field. Tomato yellow leaf curl virus (TYLCV) is the major limiting factor for tomato cultivation all over the world. Its incidence is higher in tropical and subtropical areas mainly because of higher activities of whitefly (Bemisia tabaci) (Kung. 1999: Lapidot $e t$ al., 2001). It is also an important disease of tomato in Bangladesh (Rashid et al., 2001). Application of pesticides is generally suggested for the management of virus diseases in Bangladesh, but in most cases it is ineffective. Therefore, vigorous search for finding other effective alternatives is necessary. Some researchers found that trap crops may reduce incidence of TYLCV and other viruses due to delay in initial infection (Al-Musa, 1982: El-serwiy et al., 1987; Ahmed et al., 1996). But there is no report on the effect of trap crop on virus diseases prevalent in Bangladesh. The present experiment was conducted to find out the efficacy of brinjal, cucumber and okra as trap crops against whitefly to manage TYLCV on tomato.

The experiment was conducted in the experimental farm of Bangabandhu Sheikh Mujibur Rahman Agricultural University, Gazipur, Bangladesh during winter seasons of 2003-04 and 2004-05. Seedlings of brinjal (Solanum melongena), cucumber (Cucumis sativus) and okra (Abelmoschus esculentus) were raised in polyethylene bags. Seven days old seedlings of the three trap crops were planted in the experimental plots 5 days before planting tomato seedlings in between spaces kept for planting tomato seedlings. Seedlings of a susceptible tomato variety Ratan (BARI Tomato-2) were raised in a seed bed. Four weeks old apparently healthy seedlings were planted in the field maintaining $60 \mathrm{~cm}$ row to row and $50 \mathrm{~cm}$ plant to plant spacing on 30 November in both the seasons. Seven weeks after transplanting tomato seedlings, all three trap crops were removed from tomato plots. The experiment was laid out in a randomized complete block design with four replications. The unit plot size was $2 \mathrm{~m} \times 3 \mathrm{~m}$. Plots under control did not receive any trap crop.

\footnotetext{
${ }^{1}$ Senior Scientific Officer, Plant Pathology Division, BARI, Joydebpur, Gazipur-1701, ${ }^{2}$ Professor, Department of Plant Pathology, BSMRAU, Salna. Gazipur-1706, ${ }^{3}$ Professor, Department of Entomology, BSMRAU, Salna, Gazipur-1706, Bangladesh.
} 
Tomato plants were checked regularly to record the incidence of' TYLCV. Infected tomato plants were identified based on characteristic symptoms of the virus as described by Green and Kallo (1994) and Sinistera et al. (2000), such as upward curling, cupping with or without marginal chlorosis, smaller leaflets and general stunting of plants. The disease incidence was expressed in percentage based on total number of tomato plants per plot. The disease incidence was recorded 8 weeks after transplanting and before final harvest. Data on population of whitely and fruit yield were also recorded. Data were analyzed for ANOVA after square root transformation and mean was compared using MSTAT-C computer program.

Maximum of 9 whitefly adults per leaf was recorded on brinjal, followed by cucumber showing 8 adults per leaf. On tomato, the insect vector was 4 per leaf and only one adult per leaf was recorded on okra (Table 1). The results indicated that brinjal was a good trap crop against whiteflies, followed by cucumber. Okra was not an effective crop to trap the insect vector of TYLCV.

Brinjal, cucumber and okra were tested as trap crop against TYLCV. They did not influence the incidence of the virus on tomato significantly (Table 1).

Significant increase in fruit number and fruit weight per plant (kg/plant) was obtained from okra and cucumber as compared to control where no trap crop was used. However, efficacy of the two crops to increase yield was not significantly different. Effect of the trap crops on fruit size (weight/fruit) was not significant as compared to control (Table 1).

Table 1. Effect of trap crops on whitefly population, incidence of TYLCV and fruit yield of tomato.

\begin{tabular}{l|c|c|c|l|c|c}
\hline Trap crop & $\begin{array}{c}\text { No. of } \\
\text { whiteflies/ } \\
\text { leaf }\end{array}$ & $\begin{array}{c}\text { Disease } \\
\text { incidence } \\
\text { after 8 } \\
\text { weeks of } \\
\text { transplanting } \\
\text { (\%) }\end{array}$ & $\begin{array}{c}\text { Disease } \\
\text { incidence } \\
\text { after14 } \\
\text { weeks of } \\
\text { transplanting } \\
\text { (\%) }\end{array}$ & $\begin{array}{c}\text { Fruit yield } \\
\text { (kg/plant) }\end{array}$ & $\begin{array}{c}\text { Fruit } \\
\text { number/ } \\
\text { plant }\end{array}$ & $\begin{array}{c}\text { Fruit wt } \\
\text { (g/fruit) }\end{array}$ \\
\hline Brinjal & $9 \mathrm{a}$ & $32.0 \mathrm{a}$ & $69.52 \mathrm{a}$ & $1.36 \mathrm{bc}$ & $30 \mathrm{~b}$ & $42.20 \mathrm{~s}$ \\
Cucumber & $8 \mathrm{a}$ & $33.0 \mathrm{a}$ & $62.26 \mathrm{a}$ & $1.48 \mathrm{a}$ & $35 \mathrm{a}$ & $45.04 \mathrm{a}$ \\
Okra & $1 \mathrm{c}$ & $40.0 \mathrm{a}$ & $86.19 \mathrm{a}$ & $1.43 \mathrm{ab}$ & $34 \mathrm{a}$ & $42.20 \mathrm{a}$ \\
Control & 4b & $50.0 \mathrm{a}$ & $67.52 \mathrm{a}$ & $1.31 \mathrm{c}$ & $32 \mathrm{ab}$ & $40.04 \mathrm{a}$ \\
\hline
\end{tabular}

Means within the same column with common letter(s) do not differ significantly $(\mathrm{p}=0.05)$

Trap crops were not found to be effective in reducing the TYLCV incidence, but it could delay the virus infection to some extent. When $50 \%$ of the plants 
were infected in control plots, it was around 30\% in cucumber and brinjal inerplanted plots. It might he the reason for higher yield in the trap cropped plots. Among the trap crops, brinjal and cucumber seem to be more effective as trap crops of whiteflies than okra. Al-Musa (1982) reported the effectiveness of cucumber in delaying the incidence of TYLCV and increase of yield of tomato. Whiteflies are polyphagous insects. They tend to colonize the suitable or better host when several host plants are available. But that does not ensure that they will not feed on the less preferred host. That is why, use of trap crops can increase the disease incidence in some cases. In that situation, trap crops act as source or reservoir instead of sink (Hilje et al., 2001).

Results of the present study suggest that interplanting of cucumber could increase the yield of tomato by delaying the incidence of TYLCV.

\section{References}

Ahmed. N.E., M.B.Mohamed and A.A. Abdel-Rabman. 1996. Effects of Coriandrum sativum as a repellent to whitefly on tomato yellow leaf curl virus and yield in farmers' fields. Final Report. 121p. In: Integrated Pest Management. FAO/ARC (GCP/ SUD/ 025/ NET).

Al-Musa. A. 1982. Incidence, economic importance and control of tomato yellow leaf curl in Jordan. Plant Disease 66: 56 1-563.

E1-Serwiy, S.A., A.A. Ali and I.A. Razoki. 1987. Effect of intercropping of some host plants with tomato on population density of tobacco whitefly. Bemisia tabaci (Genn.) and the incidence of Tomato yellow leaf curl virus (TYLCV) in plastic houses. Journal of Agriculture and Water Resources Research. Plant Production 6 (2): 79-81.

Green, S.K. and G. Kalloo. 1994. Leaf curl and yellowing viruses of pepper and tomato: an overview. Technical Bulletin No. 21. Asian Vegetable Research and Development Center. Taiwan. $51 \mathrm{p}$.

Hilje, L., H.S. Costa and P.A. Stansly. 2001. Cultural practices for managing Bemisia tabaci and associated viral diseases. Crop Protection 20: 801-812.

Kung. S. 1999. Effect of net protected nursery on Tomato yellow leaf curl virus incidence and severity. ARC-AVRDC Training Report 1999. 250p. (http:www.arc_vrdc.org/pdf_files/kung (17-N ) pdf).

Lapidot, M. M. Friedmann, M. Pilowsky, R. Ben-Joseph and S. Cohen. 2001. Effect of host plant resistance to Tomato yellow leaf curl virus (TYLCV) on virus acquisition and transmission by its whitefly vector. Phytopathology 91: 1209- 1213.

Rashid, M.H.. M.M. Hossain, L. Yasmin. S.M.M. Hossain and A.K.M.M. Rahman. 2001. Leaf curl and other virus resistance in tomato and chilli. Proceedings of SAVERNET-II Final workshop, 3-8 June, Bangkok, Thailand.

Sinistera. X., C.P. Patte, S. Siewnath and J.E. Polston. 2000. Identification of yellow leaf curl virus-Is in the Bahamas. Plant Disease 84 (5): 592. 